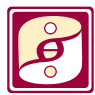

\author{
Alicja Korzeniecka-Bondar \\ Uniwersytet w Białymstoku \\ E-MAIL: alibon@uwb.edu.pl
}

\title{
O potrzebie odwagi i wysiłku w byciu nieposłusznym mainstreamowym przemianom w edukacji
}

W latach pięćdziesiątych, w okresie stalinizmu i szykanowania naukowców, Stanisław Ossowski pisał:

Pracownik naukowy to taki człowiek, do którego zawodowych obowiązków należy brak posłuszeństwa w myśleniu. Na tym polega jego służba społeczna, aby pełniąc swe zawodowe czynności nie był w myśleniu posłuszny. Pod tym względem nie wolno mu być posłusznym ani synodowi, ani komitetowi, ani ministrowi, ani cesarzowi, ani Panu Bogu. Jeżeli jest posłuszny, jeżeli poglądy swoje zmienia na rozkaz, albo jeżeli myśl jego nie jest w zgodzie z jego słowami, sprzeniewierza się swoim obowiązkom, tak jak się sprzeniewierza inżynier, który dla świętego spokoju, albo dla zysku, albo przez lenistwo, albo przez małoduszność pustakami zastępuje żelazobeton albo drewnem granit ${ }^{1}$.

W innym miejscu, opisując swoją trudną sytuację, gdy przez siedem lat nic $\mathrm{z}$ tego, co pisał, nie było publikowane, wskazuje: „W takich warunkach człowiek, jeżeli się nie załamał i nie stracił wiary w wartości, którym służył, zwraca się ku problemom bardziej zasadniczym i bardziej ryzykownym”2. Jaki to ma związek z współczesnością? Jaki ma związek z czasopismem „Parezja”?

S. Ossowski, Taktyka i kultura, [w:] J. Karpiński, Nie być w myśleniu posłusznym. (Ossowscy, socjologia, filozofia), Polonia Book Fund Ltd, London 1989, s. 136, pierwodruk: „Przegląd Kulturalny" 1956, nr 13.

2 S. Ossowski, Pisałem do szuflady. Rozmowa przeprowadzona przez J. J. Lipskiego, [w:] J. Karpiński, Nie być w myśleniu posłusznym..., s. 140-141, pierwodruk „Nowiny Literackie i Wydawnicze" 1957, nr 1.

Wybitny socjolog miał na myśli monografię, którą zamierzał wydać w 1957 roku w Wydawnictwie Ossolineum, o koncepcjach struktury klasowej w społecznej świadomości, stanowiącej „wstęp do dalszej pracy poświęconej zagadnieniom procesów spontanicznych i stosunków organizowanych w strukturze społecznej [...] funkcjom ideologii w kształtowaniu się życia społecznego". 
Tymi słowy podkreślającymi potrzebę niezależności w myśleniu, odwadze w realizowaniu zadań, które traktujemy jako swoiste zobowiązanie, ideę leżącą u podstaw powołania czasopisma „Parezja” (o czym szerzej pisałam w pierwszym numerze) chcielibyśmy wyartykułować konieczność „wyrwania się” osób zajmujących się edukacją z „błogiego zadowolenia dniem dzisiejszym”, co jest, zdaniem socjologa Franka Furediego, „charakterystycznym rysem życia umysłowego początku XXI wieku" i nadal trwa. Każdy czas i każda epoka ma swoje trudności i szanse, jak podkreśla cytowany powyżej Furedi. Jakie są te trudności i w czym można dostrzec szanse? Maria Dudzikowa w obszernym i przenikliwym eseju Niekomfortowe POŁOżENIE INSTYTUCJI UNIWERSYTETU W KŁOPOTLIWYM KONTEKŚCIE. ESEJ W TROSCE o ROZWÓJ (NIE TYLKO) KAPITA£U SPOŁECZNEGO rozpoznaje, opisuje i wnikliwie analizuje liczne zagrożenia funkcjonowania współczesnego uniwersytetu ${ }^{4}$, wśród których wymienia m.in.: mowę nienawiści, brak zaangażowania, działania pozorowane, kryzys zaufania5. Nie wpada jednak, co sama podkreśla, $\mathrm{w}$,lament nad minionym złotym wiekiem”, ale jasno ukazuje, co można czynić w tej niekomfortowej sytuacji, w jakiej znajduje się dziś uniwersytet, a dodać można - szkoła każdego szczebla kształcenia. Autorka nawołuje do obywatelskiego nieposłuszeństwa, podkreśla $\mathrm{z}$ „nadzieją w tle”, że „trzeba nam zatem i można walczyć!”’, bo tworzą się nowe intelektualne, pokoleniowe, ale i technologiczne możliwości skutecznego wpływania na kształt uniwersytetu. Przywoływana przez M. Dudzikową profesor Małgorzata Kowalska w debacie PrzyszŁość uniwersytetu, opowiadając się za powszechnym dostępem do ogólnego wykształcenia wskazuje, co można zrobić:

Stawiać opór tam, gdzie się jest. Czyli w miejscu jakoś, póki co, centralnym, czyli na uniwersytecie. Nie poddawać się bezwolnie tym wszystkim trendom, nie adaptować się tylko do stawianych nam, czasami bezmyślnych, a co najmniej bardzo kontrowersyjnych oczekiwań i wymogów, tylko je mniej lub bardziej modyfikować, krytykować, w miarę możności zabierać głos publicznie. Cóż tu innego

3 F. Furedi, Gdzie się podziali wszyscy intelektualiści?, przekł. K. Makaruk, Państwowy Instytut Wydawniczy, Warszawa 2008, s. 54.

4 Zainteresowanych analizą destrukcyjnych mechanizmów wyniszczających uniwersytet odsyłam do „Rocznika Pedagogicznego”, który poświęca tej problematyce obszerną część tomu 37, a także wcześniejszych.

5 M. Dudzikowa, Niekomfortowe położenie instytucji uniwersytetu w kłopotliwym kontekście. Esej w trosce o rozwój (nie tylko) kapitału społecznego, [w:] M. Dudzikowa, R. Wawrzyniak-Beszterda, S. Jaskulska, M. Marcianiak, E. Bochno, I. Bochno, K. Knasiecka-Falbierska, Oblicza kapitału społecznego uniwersytetu. Diagnoza - interpretacje - konteksty, t. 4, Oficyna Wydawnicza Impuls, Kraków 2013, s. 257-378.

$6 \quad$ F. Furedi, Gdzie się podziali wszyscy intelektualiści?, s. 28.

7 Ibidem, s. 377-378. 
można zrobić? Na razie tylko tyle, po to tutaj właśnie żeśmy się zebrali, żeby taką funkcję spełnićs ${ }^{8}$.

W podobnym duchu brzmią słowa Bogusława Śliwerskiego, wypowiedziane w trakcie wykładu z okazji otrzymania tytułu Doktora Honoris Causa Uniwersytetu Marii Curie-Skłodowskiej, „Intelektualiści powinni niejako rozsadzać stereotypy i rozwiązania, które ograniczają ludzką suwerenność i komunikację publiczną, stawiać opór oraz wyrażać obawy, poglądy, odczucia czy opinie także tych, którzy obawiają się konsekwencji własnej dzielności"”. W tym miejscu odsyłam Czytelnika raz jeszcze do słów S. Ossowskiego o powinnościach pracownika naukowego (rozpoczynających niniejsze wprowadzenie do tomu), które są co do istoty jednakie z głosem współczesnych badaczy mimo dystansu czasowego, który dzieli przywołanych naukowców.

Skoro pomimo różnicy problemów, nasza teraźniejszość podobnie, jak ta z czasów S. Ossowskiego, domaga się nieposłuszeństwa, to właśnie tej kategorii jest poświęcony ten numer „Parezji”. Nieposłuszeństwo rozumiem za Marią Czerepaniak-Walczak, jako proaktywną postawę

wobec dostrzeganych i/albo doświadczanych zdarzeń, sytuacji, procesów, przepisów, praw stanowiących realne lub potencjalne zagrożenie jednostkowego albo zbiorowego bytowania i rozwoju manifestującą się w zachowaniach bazujących na dywergencyjnym myśleniu, krytycznym osądzie, zawierającą elementy twórczości i innowacyjności prowadzącą do zmiany położenia osoby, układu relacji społecznych, a także nowej wiedzy oraz pól i sposobów jej wykorzystania. Nieposłuszeństwo jest niezgodą, czynnym oporem wobec doświadczanego ucisku. Działaniem na rzecz tworzenia sytuacji, które satysfakcjonują działający podmiot, zaspokajają jego potrzeby ${ }^{10}$.

Różne mogą być jego oblicza ${ }^{11}$, odmienne przejawy i zakres. Łączy je to, że nieposłuszeństwo wymaga, co podkreśla Maria Czerepaniak-Walczak, wysiłku i odwagi. Jest postawą „zawsze wobec czegoś lub kogoś. Służy komuś lub czemuś. Jest środkiem do celu, a nie celem samym w sobie. Dlatego wymaga zdawania sobie sprawy z tego cui bono fuerit, wimię czyjego dobra, kto/co

8 Przyszłość uniwersytetu. Debata z udziałem Włodzimierza Boleckiego, Tadeusza Gadacza, Małgorzaty Kowalskiej, Jacka Migasińskiego i Piotra Nowaka, „Kronos” 2011, nr 1. Źródło online: http://www.kronos.org.pl/index.php?23250,958 [19.03.2015].

9 B. Śliwerski, Pedagogika (w) demokracji, [w:] Bogusław Śliwerski Doktorem Honoris Causa Uniwersytetu Marii Curie-Skłodowskiej, Wydawnictwo Uniwersytetu Marii Curie -Skłodowskiej, Lublin 2014, s. 50.

10 M. Czerepaniak-Walczak, Sapere Aude! De omnibus est dubitandum!, rozmowę opublikowaną w tym numerze przeprowadziły Alicja Korzeniecka-Bondar i Ewa Bochno.

1 G. Sharp, Od dyktatury do demokracji. Drogi do wolności, przekł. A. Karolak, redaktor polskiego wydania M. Masziewicz, Wyd. Fundacja „Wolność i Pokój, Warszawa 2013. 
na tym skorzysta"12. W przedstawianym Czytelnikom szasopiśmie „Parezja” analizujemy nieposłuszeństwo w szeroko rozumianej edukacji. Rozważania koncentrujemy wokół pytań: kto i wobec jakich zdarzeń, sytuacji i procesów przyjmuje postawę nieposłuszeństwa? Na co się nie chcemy/ nie możemy zgodzić w obszarze edukacji? Jakie działania są potrzebne i jakie możliwe w obecnym systemie edukacji? Kto ma je podejmować? Jakiego dobra bronimy, w czyim imieniu występujemy?

Dział Studia i eseje rozpoczyna tekst Poetrka ReWolucyjna NOMADYCZNEJ MASZYNy EDUKACYJNej Oskara Szwabowskiego. Autor poddaje analizie pracę nomadycznej maszyny edukacyjnej, akcentując konieczność uwzględnienia specyfiki silnika tejże maszyny, zwłaszcza w kontekście głosu i jego relacji z tym, co ludzkie i racjonalne. Poetyka nomadycznej maszyny edukacyjnej jest, zdaniem Autora, nie tylko sposobem ujawniania się i zakrywania, ale stanowi praktykę oporową. Oskar Szwabowski, starając się zarysować budowę tego elementu silnika maszyny i jego pracę, rozważania teoretyczne odnosi do empirycznego materiału, zapomnianych historii opowiadanych przez zbuntowane wielości.

W tekście NiedostrzegAnY KRYzys PROWADZĄCY DO BUNTU Marek Piotrowski wraz z Elżbietą Kucińską i Klaudią Piotrowską próbują zidentyfikować przyczyny braku buntu wobec kryzysu systemu edukacji w Polsce. Zwracają uwagę na systemowe błędy prowadzenia badań ilościowych, wynikające z braku odpowiedniej wiedzy zarówno wśród tych, którzy zlecają analizy, jak i tych, którzy je wykonują oraz analizują błędy polskich badań będące skutkiem naśladownictwa pomiarów międzynarodowych. Taka sytuacja sprawia, że trudno dostrzec prawdziwy obraz całego systemu edukacji.

Kontynuację tych rozważań znajdziemy w tekście Marka Piotrowskiego i Elżbiety Kucińskiej Specjalistyczne Punkty Konsultacyjne - w POSZUKiWAniU wSParcia Dla ofiar systemu szkolnego. Tytułowe Specjalistyczne Punkty Konsultacyjne (SPK) zostały powołane przez samorząd Warszawy w celu rozwiązywania sytuacji konfliktowych występujących w szkołach stolicy. Punkty SPK, zatrudniające specjalistów potrzebnych do niesienia pomocy uczniom, jak i ich rodzicom, oraz nauczycielom i dyrektorom placówek oświatowych, podejmują systematyczne działania w sytuacjach kryzysowych, wydają się poprawiać jakość pracy szkół.

W dziale NA NASZE ZAPROSZENIE prezentujemy rozmowę z prof. dr hab. Marią Czerepaniak-Walczak, która zachęca wprost SAPERE Aude! De omniBUS EST DUBITANDUM!. Rozmowa przeprowadzona przez Alicję Korzeniecką-

12 M. Czerepaniak-Walczak, Sapere Aude!... 
-Bondar i Ewę Bochno dotyczy czterech głównych zagadnień: teoretycznego odczytania kategorii nieposłuszeństwa; znaczenia nieposłuszeństwa w pracy i badaniach akademików oraz funkcjonowaniu uniwersytetu; warunków (szczególnie uniwersyteckich) sprzyjających/blokujących obywatelskiemu nieposłuszeństwu; roli autorytetów w relacji Mistrz - Uczeń. W rozmowie koncentrujemy się na poszukiwaniu kontekstów kategorii nieposłuszeństwo.

Tekst Tomasza Prymaka W poszukiwaniu SKutecznego Remedium NA ZACHOWANIA RYZYKOWNE MŁODZIEŻY - O PROJEKCIE „WEŹ PRAWO W SWOJE RĘCE...”, umieszczony w części AKADEMICY NA RZECZ PRAKTYKi został poświęcony prezentacji założeń merytorycznych oraz metodycznych projektu, którego Autor jest pomysłodawcą i realizatorem. Jako pedagog i prawnik Tomasz Prymak podjął się realizacji przedsięwzięcia mającego na celu zwiększenie skuteczności działań wychowawczych i profilaktycznych na rzecz bezpieczeństwa i tworzenia przyjaznego środowiska w szkołach i placówkach. Koordynując zespołem podejmował szereg działań opisanych w tekście służących zwiększeniu świadomości prawnej młodzieży gimnazjalnej.

Anna Babicka-Wirkus w artykule Potencjaє szko£y do кszta£towaNIA OBYWATELSKIEGO NIEPOSŁUSZEŃSTWA UCZNIów przyjmuje założenie, że szkoła jako instytucja wymagająca posłuszeństwa, mimowolnie akceptuje również nieposłuszeństwo uczniów, szczególnie jeżeli przybiera ono postać obywatelskiego nieposłuszeństwa, które jest istotne w procesie kształtowania się społeczeństwa obywatelskiego.

Karina Knasiecka-Falbierska w artykule PosŁusznie o NiePosŁuszeŃSTWIE - CZYLI ANARCHISTA W SZKOLE wskazuje, że nieposłuszeństwo to jedna z cech wyróżniająca anarchistów wśród innych subkultur młodzieżowych, co przejawia się także w nastawieniu do szkoły. Autorka w oparciu o analizę literatury i czasopism anarchistycznych formułuje hipotezę, iż uczniowie anarchiści na terenie szkoły mogą stosować różne formy oporu, kontestując władzę oraz znaczenie kultury szkolnej. Wyniki przeprowadzonych przez Autorkę badań w grupie z uczniami liceów nie potwierdziły tej hipotezy. Badani przyjmują istnienie szkoły i przymus chodzenia do niej, niezależnie od stopnia zaangażowania w ruch, pragmatycznie, jako szczebel edukacji konieczny do realizacji dalszych planów życiowych. Ich krytyka szkoły i jej kultury przejawia się jedynie $\mathrm{w}$ warstwie deklaratywnej, a nie działaniowej.

Celem artykułu Przebaczenie jako dzialanie. O znaczeniu tego, co NIEPRZEWIDYWALNe DLA EDUKaCjI, autorstwa Katarzyny Szymali, jest zwrócenie uwagi na przebaczenie w aspekcie jego nieprzewidywalności (asystemowości) oraz zasygnalizowanie znaczenia tej kategorii dla edukacji i kształcenia nauczycieli. W tekście zostaje także ukazana możliwość praktycznego 
przeniesienia tej kategorii na grunt funkcjonowania szkoły jako instytucji, zgodnie ze znaczeniem, jakie nadaje przebaczeniu Hannah Arendt.

Publikujemy także dwie recenzje. Łukasz Michalski tytułuje recenzję książki Bogusława Śliwerskiego Edukacja w polityce. Polityka w eduKACJI. INSPIRACJE do BAdAŃ POLITYKi ośWiatowej (Oficyna Wydawnicza Impuls, Kraków 2015) Gra NA SERIO CZY GRA NA NOSIE? W przekonujący sposób udowadnia, że Autor recenzowanej książki na serio podchodzi do tego, jak politycy oraz w polityce "gra się na nosie" obywatelom w kwestiach edukacji.

Katarzyna Marszałek recenzuje książkę Anity Gulczyńskiej, „CHєOPAKI Z DZIELNICY". STUDIUM SPOŁECZNO-PEDAGOGICZNE Z PERSPEKTYWY INTERAKCYJNEJ (Wydawnictwo Uniwersytetu Łódzkiego, Łódź 2013), która w 2014 roku otrzymała nagrodę Łódzkiego Towarzystwa Naukowego im. Ireny Lepalczyk za prace badawcze z pedagogiki społecznej. Książka jest, co zapisano w recenzji, „zaproszeniem do podróży, w czasie której możemy odkryć uwarunkowania życia pokolenia młodych chłopaków śródmiejskiej dzielnicy".

Dorota Bis, Katarzyna Braun, Marek Jeziorański przygotowali sprawozdanie z XXVIII Letniej Szkoły Młodych Pedagogów (LSMP) wydarzenia stanowiącego główne spoiwo Forum Młodych Pedagogów przy Komitecie Nauk Pedagogicznych Polskiej Akademii Nauk (KNP PAN). Opisywana Letnia Szkoła Młodych Pedagogów organizowana była po raz dwudziesty ósmy pod patronatem Komitetu Nauk Pedagogicznych Polskiej Akademii Nauk, a po raz dwudziesty pierwszy pod kierownictwem naukowym prof. dr hab. Marii Dudzikowej. Gospodarzem tej Szkoły był Instytut Pedagogiki Katolickiego Uniwersytetu Lubelskiego, a tematem wiodącym hasło: „Opowiem Wam o swojej pasji: słowem, obrazem, dźwiękiem”. Istotą LSMP jest wspieranie i stymulowanie rozwoju naukowego młodych pedagogów, budowanie przestrzeni dla spotkań sprzyjających integracji środowisk akademickich oraz zacieśnienie więzi międzypokoleniowej.

Sylwia Jaskulska i Karol Motyl w eseju CHodź uCieKnijMY..., CZYli RZECZ O AKADEMICKIM NIEPOSŁUSZEŃSTWIE POD PRĘGIEŻEM ŚMIECHU stawiają problem nieposłuszeństwa. Autorzy zachęcają do szukania swojego miejsca w nauce i niegodzenia się/ uciekania od tego, co jest mirażem porządku, jakości. Głównymi narzędziami akademickiego nieposłuszeństwa - zdaniem Autorów - stają się „myślenie budzące ze snu” oraz „nieposłuszeństwo wobec mainstreamowych przemian, schematów, procesów, w których ujawnia się zagubiona w pogoni za konstrukcją różnych, jak nazywa je Z. Król, «bolońskich» $\mathrm{i}$ «lizbońskich» gadżetów funkcja nauki”. Akademickie nieposłuszeń- 
stwo może manifestować się na płaszczyznach naukowej, dydaktycznej i organizacyjnej, czego przykłady znajdziemy w tekście. Główną inspiracją napisania przez Autorów tego tekstu, było doświadczenie z ostatniej Letniej Szkoły Młodych Pedagogów, gdy w ramach występu Kabaretu „Beche-Co?” zaśpiewali piosenkę prezentujące dylematy młodego badacza ${ }^{13}$.

\section{Z ostatniej chwili...}

W momencie, gdy finalizujemy proces wydawniczy tego numeru „Parezji” (maj 2015) w Polsce mają miejsce ważne wydarzenia (zainicjowane znacznie wcześniej) wskazujące, że narasta fala sprzeciwu społeczności akademickiej wobec obecnej kondycji uniwersytetu. Wskażę kilka wydarzeń nie omawiając ich szerzej. Protestują studenci Uniwersytetu Warszawskiego przeciwko nowemu regulaminowi uczelni ${ }^{14}$. W wielu miastach Polski odbyły się debaty dotyczące kryzysu uniwersytetu (często z udziałem przedstawicieli Komitetu Kryzysowego Humanistyki Polskiej) ${ }^{15}$. Przed gmachem Ministerstwa Nauki i Szkolnictwa Wyższego odbył się 19.05.2015 wykład okupacyjny zorganizowany przez Komitet Kryzysowy Humanistyki Polskiej ${ }^{16}$, będący reakcją na zignorowanie przez ministerstwo postulatów popartych przez 70 instytutów naukowych z całej Polski, w którym głos zabrali profesorowie: Andrzej Leder, Przemysław Czapliński, Małgorzata Jacyno i Ewa Graczyk. W czerwcu planowana jest dalsza akcja protestacyjna środowiska akademickiego polegająca na wywieszeniu czarnych flag. Co nam ujawniają te wydarzenia (przytoczone tu jedynie jako przykład nie zaś sprawozdanie pełnego obrazu)? Bez możliwości podjęcia pogłębionej analizy, stwierdzić można, że zwiększa się liczba osób niezadowolonych z obecnego stanu funkcjonowania szkoły wyższej, którzy artykułują to na różne sposoby, co sprawia, że wzrasta także nadzieja, że są ludzie mający odwagę $\mathrm{i}$ „zdolność do podejmowania decyzji w celu powodowania zmiany w świecie" ${ }^{{ }_{17}}$. Rozpoczynałam od cytatu pochodzącego z 1957 roku, zakończę także słowami z tego okresu, tym razem Stanisława Lema:

13 Tekst piosenki dostępny na blogu B. Śliwerskiego http://sliwerski-pedagog.blogspot. com/2014/og/rat-her-be-czyli-wyscig-szczurow.html [2.12.2014].

14 http://naukawpolsce.pap.pl/aktualnosci/news,405034,studenci-uw-protestuja-przeciwkonowemu-regulaminowi-uczelni.html [15.05.2015].

${ }^{15}$ Na przykład E. Romaniuk, Co uratuje humanistów? Większe pieniądze i solidarność uczel$n i$ ?, http://bialystok.gazeta.pl/bialystok/1,35241,17925492,Co_uratuje_humanistow__Wieksze_pieniadze_i_solidarnosc.html\#ixzz3arxYf95Q [15.05.2015].

$16 \mathrm{http} / /$ naukawpolsce.pap.pl/aktualnosci/news,405065,przedstawiciele-naukowcow-protestowali-przed-gmachem-resortu-nauki.html [19.05.2015].

17 P. Freire, Education for Critical Consciousness, Continuum, New York, 1998, s. 4; podaję za P. Stańczykiem, Przemoc i emancypacja. Ambiwalencja funkcji studiów zaocznych, Wydawnictwo Uniwersytetu Gdańskiego, Gdańsk 2008, s. 137. 
„Ludzie zbudują, mimo wszystkie zawody, klęski i tragiczne omyłki, lepszy świat. Gdybyśmy nie mieli działać z tą myślą, utracilibyśmy wiarę w człowieka i jego możliwości, a wtedy lepiej byłoby nie żyć, przyjacielu”» ${ }^{\text {" }}$.

18 S. Lem, Dialogi, Wydawnictwo Literackie, Kraków 1957, s. 317. 